\title{
READERS
nsight
}

Journal of Economic Info (JEI)

ISSN:2313-3376

www.readersinsight.net/jei

\section{Impact of Performance Appraisal Reactions on Affective Organizational Commitment and Work Performance}

\author{
Kamil Hussain ${ }^{1}$ \\ ${ }^{1}$ Department of Management Sciences, University of Wah, Quaid Avenue, Wah Cantt, Pakistan \\ *Corresponding author: kamil.husain@yahoo.com
}

\begin{abstract}
The objective of the study is to examine the relationship between performance appraisal reactions and employees' outcome in terms of affective organizational commitment and work performance in Pakistan's 5 largest banks, which is situated at federal capital city, Islamabad, by using a data of 101 banking employees. The results of the survey show that performance appraisal reaction has a positive impact on organizational commitment, while it has a significant impact on work performance only for those employees whom have been receiving a high level of perceived regular feedback. This positivity describes the importance of performance appraisal reactions in high level of work performance, which was mediated by regular feedback. The results suggest that formal performance appraisal cannot compensate for low levels of regular feedback. The results derive substantial evidence of work performance by organizational commitment and performance appraisal in banking sector.
\end{abstract}

Keywords: Performance Appraisal; Organizational Commitment; Work Performance; Banking Sector
ARTICLE INFORMATION

Received: 05 May 2017

Revised: 12 July 2017

Accepted: 25 July 2017

DOI: $10.31580 /$ jei.v4i3.94

\section{INTRODUCTION}

Performance appraisal has got significant importance for optimizing the output of employees. (Armstrong, 2006) defined performance appraisal as "the formal assessment and rating of individuals by their managers at usually an annual review meeting". (Murphy and Cleveland, 1995) argued that effective performance appraisal should concentrate on clarity, openness, fairness and recognize efficiency through rewards.

There has been an improved stress on user's reactions to performance appraisal in recent years e.g. (Jawahar, 2007). (Levy and Williams, 2004) argued that user's reactions to performance appraisal and appraisal process has impact on overall effectiveness of appraisal system. (Murphy and Cleveland, 1995) argued that reactions are almost always related and critical reactions may destroy a well constructed appraisal system. In addition, (Fletcher, 2001) concluded that investigation of individual differences may influence the relationship between performance appraisal reactions and work performance that can identify certain conditions under which performance appraisal is more or less effective. (Kuvaas, 2006) found a positive relationship between performance appraisal reactions and effective organizational commitment, which was moderated by employee's intrinsic motivation. The results further reported the positive relationship between performance appraisal reactions and work performance only for employees with high level of intrinsic motivation.

Performance appraisal reactions research mostly measured some form of performance appraisal satisfaction and acceptance (Keeping and Levy, 2000). Performance appraisal reactions is defined by goal setting and feedback which is to be informative and recognizable. Goal-setting and feedback are keys to performance appraisal that is believed to affect performance positively and significantly through enhancing the information necessary for work (see (Earley et al., 1990); (Fletcher, 2001); (Neubert, 1998).

\section{Direct Relationship Between Performance Appraisal Reaction and Organizational Commitment}

Both researchers and practitioners argue that performance appraisal provide positive organizational results when it is taken in systematic way (Pettijohn et al., 2001). A great deal of attention has been given to organization commitment in past few decades. Commitment has been conceptualized and measured in many ways. Employees who are more committed have fewer intentions to leave the organization. Organizational change challenges the "way things are done in here' and, as a result, individuals experience uncertainty and start having fears about the potential failure in coping with the new situation (Denisi, A.S. \& Gonzales, 2000). Performance appraisal has the capacity to show how an individual behavior can contribute to overall group and organization goals, and thereby enhance organizational commitment (Kuvaas, 2006). Furthermore, (Latham, 2003) argued that the affective and emotional aspects of super ordinate objective may capture the "hearts" of employees (p. 309). The developmental feedback and goal-setting in Performance Appraisal probably reflects employees feeling that help in communicating super ordinate strategies, goals and vision, which increase affective organizational commitment. The study hypothesize the significant relationship between performance appraisal and effective organizational commitment in Pakistan's banking sector.

H1: There is a direct relationship between performance appraisal reactions and affective organizational commitment. 


\section{Direct Relationship Between Performance Appraisal Reaction and Work Performance}

Goal-setting and feedback are keys to performance appraisal activities in organizations (Earley et al., 1990); (Fletcher, 2001); (Neubert, 1998), which increases individual performance. Metaanalyses suggest that overall effect of feedback is positive, but the relationship between feedback intervention and performance is a complex one (Guzzo et al., 1985); (Kluger and DeNisi, 1996). Similarly, goal-setting theory has proved to be among the most important and useful theory in organizational science (Neubert, 1998). The relationship between goal-setting and performance is moderated by several factors (Locke and Latham, 2002). The study hypothesizes that employees who perceive that performance appraisal is useful and robust in terms of goal-setting and feedback also will perform well.

H2: There is a direct relationship between performance appraisal reactions and work performance.

\section{Feedback Plays a Moderating Role}

(Klein and Snell, 1994) argued that there is no standard way to conduct an appraisal interview. It depends on the situation, the relationship of the parties involved, the group and their individual make-up. (Fletcher, 2002) claimed that it is difficult for the all appraises to react in the same way to appraisal process and is probably impossible. (Ilgen et al., 1979) suggested that individual differences probably play an important role in how employees interpret appraisal feedback and how they respond to these interpretations. Consistent with these arguments empirical research suggest that autonomy orientation (Kuvaas, 2007) and employees' intrinsic motivation (Kuvaas, 2006) moderates the relationship between work performance and performance appraisal reaction. In this study, we focused on whether employee perception of day-to-day feedback plays a same role. Since the studies reviewed by (Levy and Williams, 2004) and later studies (Kuvaas, 2006) suggest that there is a positive relationship between organizational commitment and performance appraisal reactions.

(Levy and Williams, 2004) refer that the feedback environment of an organization as a proximal variable that is an integral part of the broader performance management system, and argue that factors such as perceived source credibility, quality feedback and frequency should affect appraiser's behaviors. The perceived rate of regular workrelated day-to-day feedback outside formal performance appraisal actions may moderate the relationship between work performance and performance appraisal reactions. First, if employees perceive that they get regular and day to day feedback on how they are doing their job, they may save the limited time available in formal performance appraisal activities to ask for more specific and value-added relevant goal and feedback information. Furthermore, the extent to which there is a high level of regular feedback reflects that appraisers will have more and better information about appraisees. Performance appraisal can be used to the needs of individual employees and to the issues that are not dealt on a regular basis. Accordingly, the study hypothesize that;

H3: The performance appraisal reactions and work performance relationship is moderated by regular feedback.

In contrast, necessary feedback on performance is provided more informally and on regular basis, so high levels of perceived regular feedback may also decrease the effect of performance appraisal reactions on work performance. Then, the value-addition of formal performance appraisal may be limited. In organizations where number of employees compared to the number of managers are more, it will be practically very difficult for the individual manager to provide feedback to his or her employees on regular basis. In such case, performance appraisal may require both the time and space needed for the effective exchange of information and feedback between managers and employees. Furthermore, a busy work environment could make it very difficult for managers to provide regular feedback for all employees. Similarly, if employees perceive low levels of regular feedback, they can utilize the extra effort into taking advantage of the opportunities provided by formal performance appraisal. Stating it differently, implications of performance appraisal may be stronger for those employees who experiences low levels of regular feedback because performance appraisal then can balance for lack of performance relevant information on a more regular basis. On the basis of significant discussion, the research framework of the study is presented in Figure 1 for ready reference.

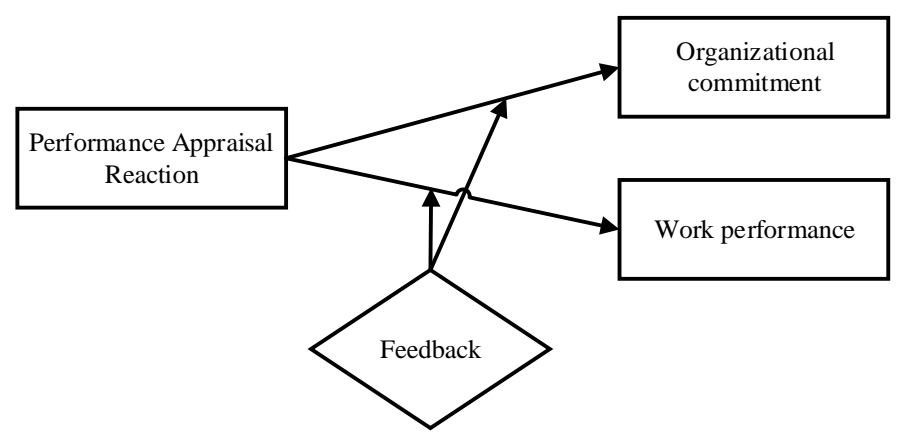

Fig. 1. Research Framework

Source: Adapted from (Kuvaas, 2010).

\section{Significance of the Study}

In today's competitive market, the continued existence of any business is only possible through maximized productivity and minimized expenses. The cost of employing labor is one of highest expenses to any business; hence, a trustworthy method of optimizing employee's or labor's productivity needs to be implemented.

Performance appraisal is such one method through which the productivity of labor/employee can be optimized. It is a formal structure that allows for the continued measuring and assessment of individual behavior and performance. Although, the purpose of this system is not only to measure the performance of human resources but also to find the areas of skill shortage in order to be enhanced and developed through feedback, identifying the potential of human resource that could be utilized in a well-organized way, and communicating and setting objectives more correctly to workers.

Just like significance of having a performance appraisal system, it is also very important to have a correct performance appraisal system. An ineffective or incorrect performance appraisal system can cause a lot of problems and can result in decreasing productivity. There is much debate about the effectiveness of even the best thought out appraisal method. Appraisers are mostly regarded as ineffective due to their leniency, personal biases, strictness, unknowingly distorting the truth (halo effect), stereotyping and other such errors. Similarly doubts are also expressed on the lack information that may result in unjust firing, which can also result in prolonged and costly legal lawsuit for unjust firing through such acts as the "Australian antidiscrimination act (1984).

It is true that regular feedback and interaction and direct maintenance by superiors would improve the performance of individuals, which as a managerial job which should never be removed. Due to these errors of the appraisers, employees can react unfavorably and can lose their commitment and can result in bad work performance. So there is a need of more research in this field being a serious issue.

\section{Problem Statement}

Despite the public speaking of performance appraisals and its affect on commitment and work performance, these relationships are generally assumed rather than tested. (Levy and Williams, 2004) argued that there is a need of more research on the relationship between performance appraisal reactions, employee attitudes and behavior. For that reason, the study examines the relationship between performance appraisal reactions, affective organizational commitment 
and work performance in the light of moderating variable, i.e. feedback.

\section{Research Objectives}

The following are the research objectives of the study, i.e.,

i) To determine the relationship between performance appraisal reactions and organizational commitment.

ii) To determine the relationship between performance appraisal reactions and work performance.

iii) To determine whether increasing the regular feedback can increase organizational commitment and work performance.

\section{DATA AND METHODOLOGY}

\section{Sample Selection}

In this study, sample was selected from five banks of Islamabad, Pakistan. The total 150 questionnaires were sent to the respective banks' employees and received 101 questionnaires dully filled and completed. The response rate was $67.3 \%$.

\section{Type of Study}

This study is qualitative in nature because it is based upon the received responses from banks' employees to examine the relationship between performance appraisal, organizational commitment, work performance, and feedback.

\section{Instrument Development/Selection}

In order to investigate the relationship between performance appraisal reactions, work performance and organization commitment, this study uses primary data through structured questionnaires. For this purpose an instrument has been adopted. The questionnaire is borrowed from (Kuvaas, 2011) that measured the items on 5 -Likert scale, which shows 1 for strongly disagree to 5 strong agree..

\section{Data Analysis Technique}

The study used different techniques for data analysis, i.e. in order to describe the general characteristics of the data and respondents' profile, the study used descriptive analysis and demographic survey respectively. Furthermore, the study used correlation and regression analysis for parameter estimates.

\section{Operationalization of Constructs}

Table 1 shows the different constructs that are used in this study for estimation.

Table 1: Constructs for estimation

\begin{tabular}{ll}
\hline Concept & Definition \\
\hline Performance & The formal assessment and \\
$\begin{array}{l}\text { appraisal } \\
\text { reaction }\end{array}$ & $\begin{array}{l}\text { rating of individuals by their } \\
\text { review meeting. }\end{array}$
\end{tabular}

$\begin{array}{ll}\text { Feed back } & \text { Feedback is key to performance } \\ & \text { appraisal activities that are widely }\end{array}$ believed to affect performance positively through enhancing the information and motivation necessary for work performance.

Organizational An individual identifies with a commitment particular organization and its goals, and wishes to maintain membership in order to facilitate these goals.

Operationalisation

The interactive role of performance

appraisal reactions and regular feedback, (Kuvass, 2010)

The interactive role of performance appraisal reactions and regular feedback, (Kuvass, 2010)

The interactive role of performance appraisal reactions and regular feedback, (Kuvass, 2010)

\begin{tabular}{lll}
\hline performance & mental, performed to complete a & performance \\
& particular task. & appraisal reactions \\
& and regular \\
& feedback, (Kuvass, \\
& $2010)$ \\
\hline
\end{tabular}

Source: (Kuvaas, 2010)

\section{DATA ANALYSIS AND RESULTS}

In this survey, 79 were males and 22 were females working in their respective banks. The majority of the employees' has a Masters degree and has 5 to 8 years of experience. On average, most of the respondents fall in the age bracket of 28-37. The study check Cronbach's alpha values on questionnaires items and find that the value fall in the range of $0.683-0.931$, which is considered in the acceptable nodes. Table 2 shows the Cronbach's alpha value for ready reference.

\begin{tabular}{lll} 
Table 2: Reliability statistics & & \\
\hline Variables & Cronbach's alpha & No of Items \\
\hline Performance appraisal & 0.762 & 6 \\
Feedback & 0.683 & 4 \\
Regular feedback & 0.684 & 4 \\
Organizational commitment & 0.770 & 6 \\
Work performance & 0.729 & 6 \\
Overall reliability & 0.931 & 26 \\
\hline
\end{tabular}

\section{Correlation Analysis}

In order to calculate the degree of association among the performance appraisal reaction, work performance, organizational commitment and feedback, this study used correlation matrix and presented the results in Table 3. Generally, the values of correlation range from -1 to +1 . This can be defined as perfect negative correlation to perfect positive correlation. The results show that correlation between performance appraisal and regular feedback is positive and statistical significant. Performance appraisal and work performance correlation is 0.579 , while the correlation value between performance appraisal and organizational commitment is 0.560. All of the correlation results confirm the positive relationship between performance appraisal reactions and its antecedents, which implies that higher the regular feedback, work performance, and organizational commitment; higher will be the performance appraisal reactions in banking sector. The correlation value is greater in work performance, followed by organizational commitment, regular feedback, and feedback, thus it shows the importance of work performance among the rest of the predictors in Pakistan's banking sector.

\section{Table 3: Correlation matrix}

\begin{tabular}{|c|c|c|c|c|c|c|}
\hline & & PA & FB & RFB & WP & OC \\
\hline \multirow[t]{3}{*}{ PA } & Pearson Correlation & 1 & & & & \\
\hline & Sig. (2-tailed) & & & & & \\
\hline & $\mathrm{N}$ & 101 & & & & \\
\hline \multirow[t]{3}{*}{ FB } & Pearson Correlation & .018 & 1 & & & \\
\hline & Sig. (2-tailed) & .120 & & & & \\
\hline & $\mathrm{N}$ & 101 & 101 & & & \\
\hline \multirow[t]{3}{*}{ RFB } & Pearson Correlation & $.532^{* *}$ & $.436^{* *}$ & 1 & & \\
\hline & Sig. (2-tailed) & .000 & .000 & & & \\
\hline & $\mathrm{N}$ & 101 & 101 & 101 & & \\
\hline \multirow[t]{3}{*}{ WP } & Pearson Correlation & $.579^{* *}$ & $.762^{* *}$ & $.741^{* *}$ & 1 & \\
\hline & Sig. (2-tailed) & .000 & .000 & .000 & & \\
\hline & $\mathrm{N}$ & 101 & 101 & 101 & 101 & \\
\hline \multirow[t]{3}{*}{ OC } & Pearson Correlation & $.560^{* *}$ & $.544^{* *}$ & $.456^{* *}$ & $.561^{* *}$ & 1 \\
\hline & Sig. (2-tailed) & .000 & .000 & .000 & .000 & \\
\hline & $\mathrm{N}$ & 101 & 101 & 101 & 101 & \\
\hline
\end{tabular}


feedback, WP shows work performance, and OC shows organizational commitment.

\section{Regression Analysis}

Regression analysis is used to find the magnitude of relationship between independent and dependent variables. It is further used to check the hypothesis of the study. The results of regression analysis are shown in the Table 5 for ready reference. The results show that performance appraisal has a positive and statistical significant impact on work performance and organizational commitment with a coefficient values of $0.599, \mathrm{p}<0.010$ and $0.459, \mathrm{p}<0.010$ respectively. The results supported the $\mathrm{H}_{1}$ and $\mathrm{H}_{2}$ hypothesis, which is related with the performance appraisal, work performance, and organizational commitment and concluded that good performance appraisal significantly increases employees' work performance and organizational commitment in Pakistan's banking sector.

Table 5: Regression analysis

\begin{tabular}{lll}
\hline Variables & $\begin{array}{l}\text { Dependent variable: } \\
\text { WP }\end{array}$ & $\begin{array}{l}\text { Dependent variable: } \\
\text { OC }\end{array}$ \\
\hline Constant & $0.966^{*}$ & 0.262 \\
PA & $0.599^{* *}$ & $0.459^{* *}$ \\
FB & 0.021 & 0.014 \\
RFB & $1.009^{\star *}$ & $0.905^{\star *}$ \\
Statistical tests & & \\
R-squared & 0.871 & 0.812 \\
Adjusted R- & 0.843 & 0.799 \\
squared & & \\
F-statistics & $9.231^{* *}$ & $6.998^{* *}$
\end{tabular}

Note: ${ }^{* \star}$ shows regression is significant at the 0.01 level. PA shows performance appraisal reactions, FB shows feedback, RFB shows regular feedback, WP shows work performance, and OC shows organizational commitment

The results are in favor of regular feedback, as it increases both the work performance and organizational commitment, while simple feedback is statistical insignificant, which clearly indicates the importance of regular feedback in organizational setting. The results conclude that there was a positive relationship between performance appraisal and work performance only for employees who perceived that they received high levels of regular feedback, which accept the $\mathrm{H}_{3}$ hypothesis. However some managers and employees may view formal performance appraisal as a way to compensate for low levels of regular day-to-day interaction between managers and subordinates. The results of this study indicate that positive performance appraisal reactions need to accompanied by high levels of regular feedback in order to be positively related to work performance. Certain level of interaction between managers and subordinates beyond formal appraisal activities may be needed for appraisers to successfully drive performance appraisal process to the needs of individual appraises. The results of this study show that regular feedback can help more in improving the work performance and organizational commitment.

\section{CONCLUSIONS}

This study suggests that reactions to performance appraisal have substantial impact on the effectiveness of appraisal systems. Still, the relationship between performance appraisal and work performance seems to be more complex than is often assumed in performance appraisal research. Many organizations in developed countries used standardized formats consisting of detailed manuals of how appraisers should conduct performance appraisal and how to perform standardized performance appraisal process. They also provide training to the appraiser in order to improve the performance appraisal process. These formats can also be adopted in Pakistan in order to make the performance appraisal process more effective. Standardized approaches may be chosen for several different purposes, for instance, to gather information and document personnel decisions (Youngcourt et al., 2007), but the moderating roles of intrinsic motivation and autonomy orientation (Kuvaas, 2006)(Kuvaas, 2007) strengthen the argument that a "one-size-fits-all" strategy will probably not increase employee performance. (Fletcher and Perry, 2002) also warned against conducting performance appraisal in a mechanical or "cookbook" fashion. (Klein and Snell, 1994) presented a personenvironment fit approach to performance appraisal, where they found a positive relationship between person-performance appraisal congruency and both turnover intention and organizational commitment. Consistent with the observation that satisfaction with performance appraisal is associated with employee commitment, performance appraisal was positively related to affective organizational commitment in the current study. This particular finding highlights the importance of positive performance appraisal reactions as the point of departure that positively influences employee attitudes in banking sector.

\section{REFERENCES}

Armstrong, M., 2006. Performance Appraisal and Performance Management. Perform. Manag. 3, 9.

Denisi, A.S. \& Gonzales, J.A., 2000. Design performance appraisal systems to improve performance. Handb. Princ. Organ. Behav. 60-72.

Earley, P.C., Northcraft, G.B., Lee, C., Lituchy, T.R., 1990. Impact of process and outcome feedback on the relation of goal setting to task performance. Acad. Manag. J. 33, 87-105.

Fletcher, C., 2002. Appraisal: an individual psychological perspective. Psychol. Manag. Individ. Perform. 115

Fletcher, C., 2001. Performance appraisal and management: The developing research agenda. J. Occup. Organ. Psychol. 74, 473-487.

Fletcher, C., Perry, E.L., 2002. Performance appraisal and feedback: A consideration of national culture and a review of contemporary research and future trends.

Guzzo, R.A., Jette, R.D., Katzell, R.A., 1985. The effects of psychologically based intervention programs on worker productivity: A meta-analysis. Pers. Psychol. 38, 275-291.

Ilgen, D.R., Fisher, C.D., Taylor, M.S., 1979. Consequences of individual feedback on behavior in organizations. J. Appl. Psychol. 64, 349.

Jawahar, I.M., 2007. The influence of perceptions of fairness on performance appraisal reactions. J. Labor Res. 28, 735-754.

Keeping, L.M., Levy, P.E., 2000. Performance appraisal reactions: Measurement, modeling, and method bias. J. Appl. Psychol. 85, 708.

Klein, H.J., Snell, S.A., 1994. The impact of interview process and context on performance appraisal interview effectiveness. J. Manag. issues 160175.

Kluger, A.N., DeNisi, A., 1996. The effects of feedback interventions on performance: A historical review, a meta-analysis, and a preliminary feedback intervention theory. Psychol. Bull. 119, 254.

Kuvaas, B., 2011. The interactive role of performance appraisal reactions and regular feedback. J. Manag. Psychol. 26, 123-137.

Kuvaas, B., 2010. Exploring alternative relationships between perceived investment in employee development, perceived supervisor support and employee outcomes. Hum. Resour. Manag. J. 20, 138-156.

Kuvaas, B., 2007. Different relationships between perceptions of developmental performance appraisal and work performance. Pers. Rev. 36, 378-397.

Kuvaas, B., 2006. Performance appraisal satisfaction and employee outcomes: mediating and moderating roles of work motivation. Int. J. Hum. Resour. Manag. 17, 504-522.

Latham, G.P., 2003. Goal Setting:: A Five-Step Approach to Behavior Change. Organ. Dyn. 32, 309-318.

Levy, P.E., Williams, J.R., 2004. The social context of performance appraisal: A review and framework for the future. J. Manage. 30, 881-905.

Locke, E.A., Latham, G.P., 2002. Building a practically useful theory of goal setting and task motivation: A 35-year odyssey. Am. Psychol. 57, 705.

Murphy, K.R., Cleveland, J.N., 1995. Understanding performance appraisal: Social, organizational, and goal-based perspectives. Sage.

Neubert, M.J., 1998. The value of feedback and goal setting over goal setting alone and potential moderators of this effect: A meta-analysis. Hum. Perform. 11, 321-335.

Pettijohn, C., Pettijohn, L.S., Taylor, A.J., Keillor, B.D., 2001. Are performance appraisals a bureaucratic exercise or can they be used to enhance sales-force satisfaction and commitment? Psychol. Mark. 18, 337-364.

Youngcourt, S.S., Leiva, P.I., Jones, R.G., 2007. Perceived purposes of performance appraisal: Correlates of individual-and position-focused purposes on attitudinal outcomes. Hum. Resour. Dev. Q. 18, 315-343. 


\section{APPENDIX}

Questionnaire

$\begin{array}{llll}\text { Your age: (a) } 18-27 \text { years } & \text { (b) } 28-37 \text { years. } & \text { c) } 38-47 \text { years. } & \text { d) } 48+\text { years } \\ \text { Gender: }(\text { a) Male } & \text { (b) Female } & & \end{array}$
Qualification: (a) Bachelor
(b) Master
(c) MS
(d) $\mathrm{PhD}$

How much you have experienced in this organization?
a) Less than 1 year
b) 1-3 years
c) 4-6 yearsd) $6-10$ years
e) $10+$ years

Please tick in the relevant column that best matches how much you agree or disagree with each statement.

Following are the questions related to performance appraisal reactions.

\begin{tabular}{|c|c|c|c|c|c|c|}
\hline Item & Statements & $\begin{array}{l}\text { Strongly } \\
\text { disagree }\end{array}$ & Disagree & $\begin{array}{l}\text { Neither agree } \\
\text { nor disagree }\end{array}$ & Agree & $\begin{array}{l}\text { Strongl } \\
\text { y agree }\end{array}$ \\
\hline 1 & $\begin{array}{l}\text { Performance appraisal helps me understand what is expected of me in } \\
\text { such a way that I can contribute to organizational effectiveness. }\end{array}$ & & & & & \\
\hline 2 & $\begin{array}{l}\text { Performance appraisal provides me with information about } \\
\text { organizational goals. }\end{array}$ & & & & & \\
\hline 3 & $\begin{array}{l}\text { Performance appraisal helps me understand the organization's vision } \\
\text { and strategy. }\end{array}$ & & & & & \\
\hline 4 & $\begin{array}{l}\text { Performance appraisal provides clear goals. I can direct attention to } \\
\text { goal setting. }\end{array}$ & & & & & \\
\hline 5 & $\begin{array}{l}\text { Performance appraisal helps me prioritize between different work } \\
\text { activities. }\end{array}$ & & & & & \\
\hline 6 & $\begin{array}{l}\text { I see clear coherence between my own work and the performance of } \\
\text { my department. }\end{array}$ & & & & & \\
\hline \multicolumn{7}{|c|}{ ollowing are the questions related to Feed Back. } \\
\hline Items & Statements & $\begin{array}{l}\text { Strongly } \\
\text { disagree }\end{array}$ & Disagree & $\begin{array}{l}\text { Neither agree } \\
\text { nor disagree }\end{array}$ & Agree & $\begin{array}{l}\text { Strongl } \\
\text { y agree }\end{array}$ \\
\hline 1 & $\begin{array}{l}\text { Performance appraisal provides clear and direct information about my } \\
\text { standing in relation to the goals of my department. }\end{array}$ & & & & & \\
\hline 2 & $\begin{array}{l}\text { The feedback I receive helps me understand the organization's } \\
\text { strategy. }\end{array}$ & & & & & \\
\hline 3 & Performance appraisal reaction provides useful feedback. & & & & & \\
\hline 4 & The feedback I receive agrees with what I have actually achieved. & & & & & \\
\hline
\end{tabular}

\section{Following are the questions are related to Regular feedback.}

\begin{tabular}{|c|c|c|c|c|c|c|}
\hline Items & Statements & $\begin{array}{l}\text { Strongly } \\
\text { disagree }\end{array}$ & Disagree & $\begin{array}{l}\text { Neither agree } \\
\text { nor disagree }\end{array}$ & Agree & $\begin{array}{l}\text { Strongly } \\
\text { agree }\end{array}$ \\
\hline 1 & I receive frequent and continuous feedback on how I do my job. & & & & & \\
\hline 2 & $\begin{array}{l}\text { I receive clear and direct information about my work performance } \\
\text { through continuously provided feedback. }\end{array}$ & & & & & \\
\hline 3 & $\begin{array}{l}\text { In my job, I'm continuously informed about what I have done well or } \\
\text { what I could have done better. }\end{array}$ & & & & & \\
\hline 4 & $\begin{array}{l}\text { I know little about what my colleagues think about my work } \\
\text { performance. }\end{array}$ & & & & & \\
\hline
\end{tabular}

Following are the questions are related to Work Performance.

\begin{tabular}{|c|c|c|c|c|c|c|}
\hline Items & Statements & $\begin{array}{l}\text { Strongly } \\
\text { disagree }\end{array}$ & Disagree & $\begin{array}{l}\text { Neither agree } \\
\text { nor disagree }\end{array}$ & Agree & $\begin{array}{l}\text { Strongly } \\
\text { agree }\end{array}$ \\
\hline 1 & $\begin{array}{l}\text { I almost always perform better than what can be characterized as } \\
\text { acceptable performance. }\end{array}$ & & & & & \\
\hline 2 & I try to work as hard as possible. & & & & & \\
\hline 3 & I often expend extra effort in carrying out my job. & & & & & \\
\hline 4 & I often perform better than can be expected. & & & & & \\
\hline 5 & The quality of my work is top-notch. & & & & & \\
\hline 6 & I'm very engaged on doing a job while at work. & & & & & \\
\hline
\end{tabular}

Following are the questions are related to affective organizational commitment.

\begin{tabular}{|c|c|c|c|c|c|c|}
\hline Items & Statements & $\begin{array}{l}\text { Strongly } \\
\text { disagree }\end{array}$ & Disagree & $\begin{array}{l}\text { Neither agree } \\
\text { nor disagree }\end{array}$ & Agree & $\begin{array}{l}\text { Strongly } \\
\text { agree }\end{array}$ \\
\hline 1 & I do not feel "emotionally attached" to this organization. & & & & & \\
\hline 2 & I do not feel like "part of the family" at my organization. & & & & & \\
\hline 3 & I do not feel a strong sense of belonging to my organization. & & & & & \\
\hline 4 & This organization has a great deal of personal meaning for me. & & & & & \\
\hline 5 & I really feel as if this organization's problems are my own. & & & & & \\
\hline 6 & $\begin{array}{l}\text { I would be very happy to spend the rest of my career in this } \\
\text { organization. }\end{array}$ & & & & & \\
\hline
\end{tabular}

